\title{
Quantification of airborne moulds in the homes of children with and without wheeze
}

\author{
David P Strachan, Brian Flannigan, Eileen M McCabe, Frances McGarry
}

\begin{abstract}
A population survey of 10007 year old children found a significant excess of wheeze among children whose homes were reported to be mouldy (odds ratio $3 \cdot 70,95 \%$ confidence limits $2 \cdot 22,6 \cdot 15)$. The airborne mould flora was quantified by repeated volumetric sampling during the winter in three rooms of the homes of 88 children. All of these had previously completed spirometric tests before and after a six minute free running exercise challenge. Total airborne mould counts varied from 0 to 41000 colony forming units $(\mathrm{CFU}) / \mathrm{m}^{3}$, but were generally in the range $50-1500$ $\mathrm{CFU} / \mathrm{m}^{3}$, much lower than the concentrations found outdoors in summer. The principal types of fungi identified are all known to be common out of doors, and most were found on at least one occasion in most of the homes. Median and geometric mean total mould counts were not related to reports of visible mould in the home, or to a history of wheeze in the index child. The heterogeneous group of non-sporing fungi (mycelia sterilia) were the only airborne fungi present at significantly higher concentrations in the homes of wheezy children (geometric mean $2.1 v 0.7 \mathrm{CFU} / \mathrm{m}^{3}$. A non-significant increase in total mould counts was observed in the homes of children with a $10 \%$ or greater decline in FEV $_{1}$ after exercise (geometric mean $354 v 253$ CFU/ $\left.\mathbf{m}^{3}\right)$. Questionnaire reports of mould in the home may be a poor indicator of exposure to airborne spores. The total burden of inhaled mould spores from indoor sources is probably not an important determinant of wheeze among children in the general population. Although the association with mycelia sterilia could be a chance finding, these nonsporing isolates may include a potent source of allergen.
\end{abstract}

The possibility that fungal spores normally present in outdoor air might have a causal role in asthma and hay fever was first proposed before the second world war and became widely accepted in the $1950 \mathrm{~s}^{12} \mathrm{~A}$ review in 1981, however, pointed out that much of the evidence was anecdotal and published reports were inadequate and controversial. ${ }^{3}$ Type 1 cutaneous hypersensitivity reactions to mould extracts provide the best evidence of a causal link, but many asthmatic patients who have cutaneous hypersensitivity to fungi are also allergic to pollen or house dust mites, ${ }^{24}$ so the independent contribution of mould exposure to their symptoms may be difficult to determine. In a detailed longitudinal study of eight Dutch asthmatic subjects known to be allergic to moulds pulmonary complaints were more common when outdoor mould spore concentrations were high, but no association was found with indoor concentrations. ${ }^{5}$

Evidence of an association between asthma and indoor exposure to mould comes from a case-control study of 72 adults with asthma and 72 age and sex matched control subjects. ${ }^{6}$ Nineteen cases and nine controls reported visible mould on the walls of their homes, and there was a significantly higher prevalence of positive radio allergosorbent test (RAST) responses to Penicillium among patients reporting mould in their homes. These and other results $^{7}$ suggest that domestic mould spores may be capable of invoking species specific type 1 hypersensitivity in a small proportion of asthmatic adults.

A recent cross sectional study of children and their parents in selected areas of Glasgow, Edinburgh, and London ${ }^{8}$ found no association between reports of mould in the home and wheeze among adult respondents. A strong relation, however, was found between reported mould growth and wheeze in children, and total airborne mould spore counts were higher in the homes of wheezy children. A survey of a random sample of 7 year old children in Edinburgh ${ }^{9}$ found that the prevalence of wheeze was three times greater among children from homes reported to have visible mould growth than among children from allegedly non-mouldy homes. This confirmed earlier findings in the north west of the city. ${ }^{1011}$ Reporting of symptoms was validated by measuring exercise induced bronchoconstriction in the children. Much of the association between mould and wheeze could be attributed to biased case ascertainment, but there were nevertheless more children with exercise induced bronchoconstriction among the group from mouldly homes.'

The reporting of visible mould in the home may differ between asthmatic and nonasthmatic individuals, owing to a tendency for asthmatic patients (or their parents) to seek an identifiable cause for the complaint in their home environment. In the Edinburgh study ${ }^{9}$ the possibility of differential reporting of housing conditions was initially evaluated by measurements of temperature and relative 
humidity in the child's bedroom. No differences were found between the bedroom conditions of children with and without wheeze. ${ }^{12}$ Ambient humidity may be a poor indicator of conditions in specific indoor microenvironments, where penetrating moisture or condensation on to cold surfaces promotes the growth of moulds. ${ }^{13}$ The study was therefore extended to measure exposure to airborne mould spores among children with and without wheeze. We postulated that, if substantial reporting bias had occurred, the reports of mould growth by parents of wheezy children would be associated with lower levels of measured exposure than similar reports by parents of unaffected children.

\section{Methods}

POPULATION SURVEY

The original questionnaire survey and medical examinations have been described elsewhere. ${ }^{9}$ Briefly, a random sample of children in their third primary year (age $61 / 2$ to $71 / 2$ in September 1986) were chosen. Parents were asked to complete a postal questionnaire that inquired about recent respiratory symptoms experienced by the child and conditions in the home, with particular reference to dampness and visible mould growth. The study received ethical approval from the Lothian Health Board and Lothian Regional Council department of education.

With parental consent, children were examined by one author (DPS) at school during the first half of 1987, using the American Thoracic Society protocol. ${ }^{14}$ A "Compact" pneumotachograph (Vitalograph Ltd, Buckingham) was used to record forced expiratory spirograms before and after a six minute free running exercise challenge. The minimum of two satisfactory recordings of forced expiratory volume in one second $\left(\mathrm{FEV}_{\mathrm{t}}\right)$ taken five and 10 minutes after exercise was compared with the pre-exercise recording. Bronchial lability was defined as the difference between the postexercise and pre-exercise $\mathrm{FEV}_{1}$ divided by the pre-exercise $\mathrm{FEV}_{1}$.

At the conclusion of the mycological survey in March 1988 the parents of each child were asked to complete a short questionnaire relating to respiratory symptoms during the previous year. No further measurements of ventilatory function or bronchial lability were made.

\section{SELECTION OF HOMES}

One third of the children in the main survey were selected for continuous measurement of temperature and relative humidity in their bedroom for seven days, from January to April 1987. This sample was stratified by estimated bedroom relative humidity, to include all the most humid bedrooms and a one in four sample of the remainder. ${ }^{12}$ The present study was based on a subsample of this group. An attempt was made to include all the children with wheeze, and all those whose parents had reported visible mould in the home in the original questionnaire. A random sample of one in eight of those with neither wheeze nor mould were also asked to participate. Families who had moved house since the questionnaire survey were excluded from the study.

During the six months October 1987 to March 1988 each home was visited four times (at approximately monthly intervals) for sampling of air in three rooms with a volumetric Andersen sampler. ${ }^{15}$ In each home samples were taken in the living room and the child's bedroom. If visible mould was a problem elsewhere in the house (21 homes), a third sample was taken in that room (other bedroom nine, bathroom 11, hallway one). Otherwise, the third sample was taken in the kitchen (67 homes).

\section{MYCOLOGICAL METHODS}

A six stage Andersen 1ACFM Viable Particle Sampler (Andersen 2000 Inc, Atlanta, Georgia, USA) was used to sample air for viable mould spores and yeasts. The intake orifice was placed about $45 \mathrm{~cm}$ above floor level, and the instrument was operated according to the manufacturer's instructions except that $9.0 \mathrm{~cm}$ disposable plastic Petri dishes were used as collection plates. Each plate contained $27 \mathrm{ml}$ sterile malt agar $\left(2^{\circ}{ }_{0}(\mathrm{w} / \mathrm{v})\right.$ malt extract, $1.2^{\circ}$, Agar No 3 (Oxoid)) with 20 units $/ \mathrm{ml}$ benzylpenicillin and $0.05 \mathrm{mg} / \mathrm{ml}$ streptomycin sulphate to inhibit bacterial growth. After 85 litres of air had been sampled over three minutes the plates were incubated at $25^{\circ} \mathrm{C}$ for seven days. Counts of colony forming units (CFU) were computed from the numbers of colonies developing on the plates, correction being made by the "positive hole" method recommended by the manufacturer. ${ }^{15}$ For identification, fungi were isolated on to potato dextrose agar (Oxoid) plates incubated at $25^{\circ} \mathrm{C}$, and identified by reference to standard texts ${ }^{16}$ and by comparison with reference strains.

Isolates of mycelial fungi (that is, the vegetative, non-sporing hyphae), which because they did not sporulate in culture on either medium could not be identified, were plated out on $3^{\circ}$ malt extract tannic acid agar to test for production of diphenol oxidase. ${ }^{16}$ Those that were positive were classified as basidiomycetes capable of causing white rot of wood. Those that did not sporulate, did not produce diphenol oxidase, and did not show the clamp connections characteristic of the class Basidiomycetes family were categorised together as mycelia sterilia-that is, nonsporing fungi.

\section{STATISTICAL ANALYSIS}

Statistical analysis was performed by means of the Statistical Analysis System (SAS). ${ }^{17}$ In quantitative comparisons a logarithmic transformation was used for fungal counts to correct for the positively skewed distribution. For this purpose, zero counts were treated as $0 \cdot 1$ $\mathrm{CFU} / \mathrm{m}^{3}$. Observations from the "no mould and no wheeze" group were assigned a weight of 8 in the calculation of geometric means, to allow for the sampling fraction of $1 / 8$ in this group. Weighting was also used in comparisons of means by one way analysis of variance, the GLM procedure in $S_{A S}{ }^{17}$ being used. 
Table 1 Relation between reported mould and wheeze in the population survey and the derivation of the study sample

\begin{tabular}{|c|c|c|c|c|c|}
\hline \multirow{3}{*}{$\begin{array}{l}\text { Simptom report Nov 1986: } \\
\text { Home condition Nov' 1986: } \\
\text { Group: }\end{array}$} & \multicolumn{4}{|c|}{ No of chifldren, with } & \multirow[b]{3}{*}{$\begin{array}{l}\text { Odds ratio ( } 95 \% \text { CL) } \\
\text { for wheeze v mould }\end{array}$} \\
\hline & \multicolumn{2}{|c|}{ Wheezze past year } & \multicolumn{2}{|c|}{ No wheeze past year } & \\
\hline & $\begin{array}{l}\text { Mould } \\
A\end{array}$ & $\begin{array}{l}\text { No mould } \\
B\end{array}$ & $\begin{array}{l}\text { Mould } \\
\text { C }\end{array}$ & $\begin{array}{l}\text { No mould } \\
D\end{array}$ & \\
\hline Questionnaire survey (9) & 27 & 96 & 62 & 815 & $3 \cdot 70(2 \cdot 22-6 \cdot 15)$ \\
\hline Bedroom monitored (12) & 15 & 30 & 38 & 247 & $3.25(1.60-6.60)$ \\
\hline Target sample & 15 & 30 & 38 & 31 & \\
\hline Moved & 2 & 5 & 6 & 5 & \\
\hline Refused & 1 & 2 & 1 & 1 & \\
\hline No contact & 1 & 0 & 2 & 0 & \\
\hline Achieved sample & 11 & 23 & 29 & 25 & \\
\hline
\end{tabular}

\section{Results}

POPULATION SURVEY

The original questionnaire survey obtained usable data from $1000\left(91^{\circ}{ }_{11}\right)$ of the 1095 children selected as a random sample of the population. Table 1 shows the numbers of children who were reported by their parents to have wheezed in the past year, and to have visible mould growth in the home. The association between mould and wheeze was highly significant $(\mathrm{p}<0.0001)$, and was largely independent of other social and housing variables." Among the 330 children whose bedroom conditions were monitored for temperature and relative humidity during January-April $1987^{12}$ the association was of similar strength (table 1).

\section{SAMPLE SELECTION}

Among the target sample for the present study, 18 families were excluded because they had moved house, five refused to participate in further studies, and no visits could be arranged with three families who initially agreed to participate. The overall response rate for sampling of airborne fungi was therefore $77^{\circ}$, (88 of the 114 homes in the target sample). The response rate did not differ substantially in the four "wheeze-mould" groups (table 1).

Although the sample was chosen on the basis of questionnaire data obtained one year earlier, $29\left(85^{\circ}\right)$ of the 34 children with wheeze reported in the questionnaire were still wheezing during the winter of 1987-8. Our fieldworkers observed mould growth in few of the homes that they visited. This probably reflects the exceptionally warm winter conditions during the period of the survey. The incidence of mould growth was higher, however, in the homes reported to be mouldy in 1986; five of 11 homes in group A (wheeze and mould); two of 23 homes in group B (wheeze and no mould); five of 29 homes in group C (mould and no wheeze); and one of 25 homes in group D (no mould and no wheeze).

\section{DISTRIBUTION OF TOTAL MOULD COUNTS}

Table 2 shows the distribution of total (all species) counts of colony forming units obtained from each air sample, by sampling site and wheeze-mould group. There was a wide range of values, but only three samples (two from group B, one from group C) had more than $10000 \mathrm{CFU} / \mathrm{m}^{3}$ of air. Six air samples contained no viable moulds. In relation to the variation between homes in each group, the median counts for each group at each sampling site were remarkably similar.

TYPES OF MOULD ISOLATED

Nearly 50 species or genera of fungi were identified in air samples. Table 3 shows the principal types isolated in each wheeze-mould group. Yeasts were isolated on most occasions, but were not included in the total mould count. Spores of Penicillium spp and Cladosporium spp were isolated from at least one room in all homes on every occasion. Together they accounted for about half of the total mould count. Only the heterogeneous group of airborne mycelia sterilia appeared to bear any relation to the questionnaire reports of visible mould in the home, being particularly evident in the homes of children with wheeze and visible mould growth (table 3 ). Less common fungi included various Aspergillus species, most frequently $A$ glaucus. $A$ fumigatus, $A$ nidulanus, and $A$ terreus were occasionally isolated, but never in large numbers.

\section{MOULD COUNTS, WHEEZE, AND BRONCHIAL}

LABILITY

Weighted geometric mean mould counts for children with and without a history of wheeze and with and without exercise induced bronchospasm are shown in table 4 . The differences

Table 2 Distribution of total airborne mould counts (CFU per $\mathrm{m}^{3}$ ) by site of sampling and subjects grouped according to the reporting of wheeze and mould, all visits combined

\begin{tabular}{|c|c|c|c|c|c|c|c|c|c|c|c|c|}
\hline \multirow{2}{*}{$\begin{array}{l}\text { Room sampled: } \\
\text { Wheeze: } \\
\text { Mould: } \\
\text { Group }{ }^{\star}:\end{array}$} & \multicolumn{4}{|c|}{ Living room } & \multicolumn{4}{|c|}{ Child's bedroom } & \multicolumn{4}{|c|}{ Other room $\dagger$} \\
\hline & $\begin{array}{l}\text { Yes } \\
\text { Yes } \\
A\end{array}$ & $\begin{array}{l}\text { Yes } \\
\text { No } \\
B\end{array}$ & $\begin{array}{l}\text { No } \\
\text { Yes } \\
C\end{array}$ & $\begin{array}{l}\text { No } \\
\text { No } \\
D\end{array}$ & $\begin{array}{l}\text { Yes } \\
\text { Yes } \\
A\end{array}$ & $\begin{array}{l}\text { Yes } \\
\text { No } \\
B\end{array}$ & $\begin{array}{l}\text { No } \\
\text { Yes } \\
\text { C }\end{array}$ & $\begin{array}{l}\text { No } \\
\text { No } \\
D\end{array}$ & $\begin{array}{l}\text { Yes } \\
\text { Yes } \\
A\end{array}$ & $\begin{array}{l}\text { Yes } \\
\text { No } \\
B\end{array}$ & $\begin{array}{l}\text { No } \\
\text { Yes } \\
\text { C }\end{array}$ & $\begin{array}{l}\text { No } \\
\text { No } \\
D\end{array}$ \\
\hline $\begin{array}{l}\text { Minimum } \\
\text { Lower quartile } \\
\text { Median } \\
\text { Upper quartile } \\
\text { Maximum } \\
\text { No of samples }\end{array}$ & $\begin{array}{r}47 \\
177 \\
294 \\
553 \\
2895 \\
41\end{array}$ & $\begin{array}{r}35 \\
153 \\
271 \\
659 \\
38594 \\
91\end{array}$ & $\begin{array}{r}0 \\
153 \\
283 \\
483 \\
4531 \\
112\end{array}$ & $\begin{array}{r}12 \\
129 \\
271 \\
789 \\
6038 \\
95\end{array}$ & $\begin{array}{r}0 \\
106 \\
200 \\
330 \\
3072 \\
41\end{array}$ & $\begin{array}{r}12 \\
130 \\
212 \\
447 \\
2695 \\
91\end{array}$ & $\begin{array}{r}12 \\
141 \\
224 \\
424 \\
41265 \\
111\end{array}$ & $\begin{array}{r}0 \\
106 \\
247 \\
459 \\
7168 \\
95\end{array}$ & $\begin{array}{r}59 \\
177 \\
247 \\
412 \\
5049 \\
41\end{array}$ & $\begin{array}{r}0 \\
153 \\
283 \\
636 \\
36946 \\
91\end{array}$ & $\begin{array}{r}0 \\
152 \\
269 \\
445 \\
3637 \\
111\end{array}$ & $\begin{array}{r}0 \\
130 \\
271 \\
883 \\
9534 \\
96\end{array}$ \\
\hline
\end{tabular}

$\star$ As in table 1.

tSee text for details. 
Table 3 Principal types of fungi identified in air samples, by wheeze-mould group

\begin{tabular}{|c|c|c|c|c|c|c|c|c|}
\hline \multirow[b]{3}{*}{$\begin{array}{l}\text { Wheeze reported: } \\
\text { Mould reported: } \\
\text { Group }{ }^{\star}\end{array}$} & \multicolumn{8}{|c|}{ Number of homes in which the fungus was isolated } \\
\hline & \multicolumn{4}{|c|}{ At any one visit } & \multicolumn{4}{|c|}{ At each visit } \\
\hline & $\begin{array}{l}\text { Yes } \\
\text { Yes } \\
A\end{array}$ & $\begin{array}{l}\text { Yes } \\
\text { No } \\
\text { B }\end{array}$ & $\begin{array}{l}\text { No } \\
\text { Yes } \\
\text { C }\end{array}$ & $\begin{array}{l}\text { No } \\
\text { No } \\
D\end{array}$ & $\begin{array}{l}\text { Yes } \\
\text { Yes } \\
A\end{array}$ & $\begin{array}{l}\text { Yes } \\
\text { No } \\
\text { B }\end{array}$ & $\begin{array}{l}\text { No } \\
\text { Yes } \\
C\end{array}$ & $\begin{array}{l}\text { No } \\
\text { No } \\
D\end{array}$ \\
\hline $\begin{array}{l}\text { Yeasts } \dagger \\
\text { Penicillium spp } \\
\text { Cladosporium spp } \\
\text { Sistotrema brinkmanii } \\
\text { White rot basidiomycetes } \\
\text { Mycelia sterilia } \\
\text { Aspergillus versicolor } \\
\text { Aureobasidium pullulans } \\
\text { Botrytis cinerea }\end{array}$ & $\begin{array}{l}11 \\
11 \\
11 \\
11 \\
11 \\
11 \\
11 \\
11 \\
7\end{array}$ & $\begin{array}{l}23 \\
23 \\
23 \\
23 \\
23 \\
22 \\
21 \\
18 \\
15\end{array}$ & $\begin{array}{l}29 \\
29 \\
29 \\
28 \\
28 \\
28 \\
28 \\
22 \\
16\end{array}$ & $\begin{array}{l}25 \\
25 \\
25 \\
24 \\
25 \\
23 \\
21 \\
15 \\
18\end{array}$ & $\begin{array}{r}10 \\
11 \\
11 \\
5 \\
5 \\
8 \\
2 \\
0 \\
0\end{array}$ & $\begin{array}{r}21 \\
23 \\
23 \\
10 \\
7 \\
5 \\
2 \\
1 \\
0\end{array}$ & $\begin{array}{r}28 \\
29 \\
29 \\
12 \\
14 \\
7 \\
5 \\
0 \\
0\end{array}$ & $\begin{array}{r}25 \\
25 \\
25 \\
11 \\
5 \\
4 \\
1 \\
2 \\
1\end{array}$ \\
\hline No of homes visited & 11 & 23 & 29 & 25 & 11 & 23 & 29 & 25 \\
\hline
\end{tabular}

$\star$ As in table 1 .

+Yeasts were excluded from the total mould counts.

between geometric mean counts for all species combined were small and inconsistent; counts were slightly lower in the homes of wheezy children than in the homes of non-wheezy children, but somewhat higher in the homes of children with exercise induced bronchospasm than in the remainder of the sample; these differences, however, could easily have occurred by chance.

The geometric mean counts for the five most common groups of moulds in the homes of children with and without wheeze and with and without exercise induced bronchoconstriction are shown in table 4. For Penicillium spp, Cladosporium spp, Sistotrema brinkmanii, and white rot basidiomycetes the differences were non-significant and in opposing directions for wheeze and bronchial lability. Non-sporing mycelia sterilia were generally found in low concentrations, but were present at higher levels in the homes of both the wheezy children and those with exercise induced bronchoconstriction. When the homes of wheezy and nonwheezy children were compared, the difference in weighted geometric mean counts of mycelia sterilia was significant $(p<0.01)$, but this significance test should be interpreted in the light of the multiple comparisons that could have been made in table 4 .

\section{Discussion}

This study is the first to compare, in both quantitative and qualitative terms, the indoor mould flora of samples from homes of symptomatic and symptomless individuals from the

Table 4 Geometric mean airborne mould counts ( $C F U$ per $m^{3}$ ), all visits combined, by history of wheeze and degree of exercise induced bronchial lability during 1986-7

\begin{tabular}{|c|c|c|c|c|c|c|c|}
\hline \multirow[b]{2}{*}{ Room sampled } & \multirow[b]{2}{*}{ Fungus } & \multicolumn{3}{|c|}{ Wheeze in past year } & \multicolumn{3}{|c|}{ Bronchial lability $>10 \% \ddagger$} \\
\hline & & Yes & No & $(t+)$ & Yes & No & $(t \dagger)$ \\
\hline $\begin{array}{l}\text { Living } \\
\text { Child's } \\
\text { Other } \\
\text { Pooled samples } \\
\text { Penicillium spp } \\
\text { Cladosporium s } \\
\text { Sistotrema brin } \\
\text { White rot basid } \\
\text { Mycelia sterilia }\end{array}$ & $\begin{array}{l}\text { Total } \\
\text { Total } \\
\text { Total } \\
\text { Total } \\
\text { pp } \\
\text { diomanii } \\
\text { diomycetes }\end{array}$ & $\begin{array}{c}304 \\
223 \\
309 \\
276 \\
39 \\
16 \\
5 \cdot 1 \\
2 \cdot 5 \\
2 \cdot 1\end{array}$ & $\begin{array}{c}311 \\
229 \\
314 \\
281 \\
55 \\
12 \\
3 \cdot 4 \\
1 \cdot 3 \\
0 \cdot 7\end{array}$ & $\begin{array}{l}-0.08 \\
-0.07 \\
-0.04 \\
-0.07 \\
-0.78 \\
+0.46 \\
+0.63 \\
+1.45 \\
+2.84\end{array}$ & $\begin{array}{c}381 \\
285 \\
407 \\
354 \\
62 \\
12 \\
3 \cdot 1 \\
1.0 \\
1.0\end{array}$ & $\begin{array}{c}282 \\
206 \\
278 \\
253 \\
49 \\
13 \\
3 \cdot 8 \\
1 \cdot 7 \\
0 \cdot 7\end{array}$ & $\begin{array}{l}+1.52 \\
+1 \cdot 28 \\
+1.67 \\
+1.63 \\
+0.75 \\
-0.30 \\
-0.18 \\
-1.70 \\
+1.11\end{array}$ \\
\hline No of children & & 34 & 54 & & 26 & 62 & \\
\hline
\end{tabular}

* Log counts weighted for the different sampling fractions in groups A-D.

+Student's $t$ test with 88 degrees of freedom.

+ Reduction in $\mathrm{FEV}_{1}$ of $>10^{\circ}{ }^{\circ}$ of pre-exercise value, at either five or 10 minutes after six minute free running exercise challenge. general population. The viable mould counts that we obtained from three minute air samples may not adequately reflect peaks and troughs of exposure but, to put them in perspective, only three of the samples in our study approached the levels of $10000-50000 \mathrm{CFU} / \mathrm{m}^{3}$ that are typical of a summer garden. ${ }^{19} 20$ Occupational exposures that are implicated in allergic alveolitis, such as the handling of mouldy hay, are associated with airborne spore burdens of a different order of magnitude, reaching $1600000000 / \mathrm{m}^{3}$ at times. ${ }^{21}$

Until recently there was little published information on the extent to which indoor mould growth affects the composition of the domestic air spora in the United Kingdom..$^{223}$ A survey in 60 occupied council houses in London and three Scottish towns ${ }^{18}$ found, as we did, considerable differences in the total airborne spore burden, not only between homes but also with repeated sampling within homes. This variation is probably related to domestic activity, as spores are found in large numbers in house dust (100 000-1 $000000 / \mathrm{g}$ dust. ${ }^{24}$ Homes with visible mould had somewhat higher airborne mould counts, generally in the range $1000-2000 \mathrm{CFU} / \mathrm{m}^{3}$, with skewing of the distribution towards high values. ${ }^{18}$ This suggests that mould growth on walls does increase the average indoor spore burden (which is usually much higher than the outdoor burden in winter), though even these higher concentrations are modest by comparison with summer outdoor concentrations. The lower spore counts in our study may reflect the mild winter conditions that we encountered; but our sample of mouldy homes, being based on questionnaire responses, probably included fewer severe cases of mould growth than homes that have been the subject of complaint to local authorities ${ }^{18}$ or private landlords.

Although valuable in comparing different homes, volumetric sampling may underestimate the true exposure of mobile people to fungal spores. Spores may be released from house dust by movement in the room and enter convection currents around the warm body, which are estimated to contribute $10 \%$ of inspired air. ${ }^{25}$ The count of viable spores or colony forming units of any one species, or of all species combined, may be of limited clinical and epidemiological relevance if spores from different species have different allergenic potential, ${ }^{26}$ or if hypersensitivity reactions can also be provoked by non-viable spores-which predominate, for example, in the air of some agricultural environments. ${ }^{27}$

Many of the types of indoor mould fungi isolated here and in the above studies, ${ }^{182223}$ however, were similar to those normally found out of doors, so mould growth in most homes seems unlikely to influence the quality of the indoor fungal flora to an important extent. Furthermore, most of the species that were identified indoors in the present study, including the highly allergenic spores of Botrytis and Aspergillus spp, ${ }^{26}$ were isolated on at least one occasion in most homes. This suggests that most people are exposed to some extent to a wide range of fungi in the indoor air, quite 
apart from their shared exposure to airborne spores out of doors.

Fewer asthmatic individuals have cutaneous hypersensitivity to extracts of mould fungi than to house dust mite, but such reactions are not uncommon. ${ }^{2}$ Reported prevalence estimates vary from $3-4 \%$ in Sweden to $80 \%$ in the United States. ${ }^{3}$ Among 656 asthmatic patients attending an immunological outpatient clinic in London, $13 \%$ had positive skin test responses to $A$ fumigatus and $18 \%$ to other fungal species. ${ }^{4}$

We found that the concentration of airborne moulds in the home varies widely between houses so that, if indoor moulds were of aetiological relevance in childhood asthma, we would expect airborne mould counts to be higher in the homes of wheezy children. The fact that little difference was found is in striking contrast to the results of the original questionnaire study. The discrepancy appears to arise partly from bias in the reporting of symptoms ${ }^{9}$ and partly because mild to moderate visible indoor mould growth has only a minor influence on the airborne mould flora inside the home, compared with dust raising household activities such as cleaning. We rset out to investigate the possibility that reporting of mould is more likely where a child has asthma. The absence of any difference between median counts of colony forming units in mouldy homes with and without a wheezy child (groups $A$ and C) may not be remarkable as the airborne spore burden differed so little between mouldy and non-mouldy homes.

Mycelia sterilia were cultured more frequently from air samples taken in the homes reported to be mouldy, and were present in higher concentrations in the homes of wheezy children. Further studies of these heterogeneous fungi are required to confirm these associations. Particular attention is being paid to them in continuing studies of both viable and non-viable airborne moulds.

The appearance of mycelia in air samples is consistent with several explanations. Firstly, the air samples may include spores from species that do not sporulate in vitro on the culture media used, so that they cannot be assigned to species or genus. Alternatively, fragments of mycelium from fungi that are not currently sporing may become detached from their substrate and wafted into passing air currents. Thirdly, the substrate itself may become airborne and carry non-sporing mould fungi with it. Faecal particles from the house dust mite Dermatophagoides pteronyssinus are known to become airborne and contain potent allergens, so the association between non-sporing fungal isolates and wheeze could perhaps reflect the occurrence of moulds on mite faeces. Before any link can be confirmed between mycelia sterilia and childhood asthma, the source, nature, and allergenicity of the various components should be clarified.

The conclusions to be drawn from these findings are limited by the methodological difficulties of quantifying fungi in indoor air and by the relatively small number of homes studied, but they are strengthened because the relation of our study sample to the general population is well defined. Epidemiological data such as these cannot exclude the possibility of clinically important idiosyncratic reactions to domestic mould spores in a few susceptible individuals, nor do they address the possible effects on health of exceptionally high mould spore concentrations in homes severely affected by mould. ${ }^{25}$

On the other hand, they are relevant to assessing the importance of damp, mouldy housing as a public health problem and to the setting of building standards. ${ }^{28}$ The confirmation of differential reporting of both symptoms and housing conditions in questionnaire data suggests that further investigation of the link between respiratory disease and damp, mouldy housing should be based on valid and objective measurements, preferably in samples that can be related to the general population. The original questionnaire survey was carried out while DPS held a Wellcome research training fellowship, and 1986-7 fieldwork was supported by the Asthma Research Council. The
$1987-8$ fieldwork and subsequent mycological studies were 1987-8 fieldwork and subsequent mycological studies were performed at Heriot-Watt University under extramural contract
from the Department of the Environment Building Research from the Department of the Environment Building Research Establishment. We wish to thank Ms P Ross for assistance with the medical examinations, Ms B Somerville for visiting homes for bedroom monitoring, and Dr A F Bravery and Mr C A Hunter (at the Building Research Establishment) for their valuable advice throughout the fieldwork and for their comments on the text.

1 van der Werff PJ. Mold fungi and bronchial asthma. $A$ mycological and clinical study. Springfield, Illinois: Thycological and

2 Hyde HA, Richards M, Williams DA. Allergy to mould spores in Britain. Br Med J 1956;i:886-90.

3 Salvaggio J, Aukrust L. Mold-induced asthma. J Allergy Clin Immunol $1981 ; 68: 327-46$

4 Hendrick DJ, Davies RJ, d'Souza MF, Pepys J. An analysis of skin prick test reactions in 656 asthmatic patients. Thorax 1975;30:2-8.

5 Beaumont F, Kauffman HF, Sluiter HJ, de Vries K. Sequential sampling of fungal air spores inside and outside the homes of mould-sensitive asthmatic patients: a search for a relationship to obstructive reactions. Ann Allergy 1985;55:740-6.

6 Burr ML, Mullins J, Merrett TG, Stott NCH. Indoor moulds and asthma. JR Soc Health 1988;108:99-101.

7 Sherman H, Merksamer D. Skin test reactions in mold sensitive patients in relation to presence of molds in their sensitive patients in relation to presen
homes. $N Y J M e d$ 1964;64:2533-5.

8 Platt SD, Martin CJ, Hunt SM, Lewis CW. Damp housing mould growth and symptomatic health state. $\mathrm{Br} \mathrm{Med}$ 1989;298:1673-8.

9 Strachan DP. Damp housing and childhood asthma: validation of reporting of symptoms. Br Med J 1988;297:1223-6.

10 Strachan DP, Elton RA. Relationship between respiratory morbidity in children and the home environment. Fam Pract 1986;3:137-42.

11 Martin CJ, Platt SD, Hunt SM. Housing conditions and illhealth. Br Med J 1987;294:1125-7.

12 Strachan DP, Sanders CH. Damp housing and childhood asthma. Respiratory effects of indoor temperature and relative humidity. J Epidemiol Community Health 1989;43: 7-14.

13 Block SS. Humidity requirements for mould growth. Appl Microbiol 1953;1:287-93.

14 American Thoracic Society. Snowbird workshop on stan dardization of spirometry. Am Rev Respir Dis 1979;119. 831-8.

15 Andersen AA. A new sampler for the collection, sizing and enumeration of viable airborne bacteria. J Bacteriol 1958 76:471-84.

16 Stevens RB. Mycology guidebook. Seattle: University of Washington Press, 1974.

17 SAS Institute. SAS user's guide. Basics; Statistics. Version 5 edition of both volumes. Cary, North Carolina: SAS Institute, 1985.

18 Hunter CA, Grant C, Flannigan B, Bravery AF. Mould in buildings: the air spora of domestic dwellings. Int Biodeterioration 1988;24:81-101.

19 Lacey ME. The summer air. spora of two contrasting adjacent rural sites. J Gen Microbiol 1962;29:485-501.

20 Hudson HJ. Aspergilli in the air spora at Cambridge. Trans Br Mycol Soc 1969;52:153-9.

21 Lacey J, Lacey ME. Spore concentrations in the air of farm buildings. Trans Br Mycol Soc 1964;47:547-52.

22 Richards $M$. Atmospheric mold spores in and out of doors. J Allergy 1954;25:429-39.

23 Adams KF, Hyde WA. Pollen grains and fungus spore 
indoors and out at Cardiff. Journal of Palynology 1965;1: 67-9.

24 Institute of Environmental Health Officers. Mould fungal spores-their effects upon health, and the control, prevention and treatment of mould growth in dwellings.
vents London: Institute of Environmental Health Officers, London:

25 Holmberg K. Mould growth inside buildings. In: Berglund $\mathrm{B}$, Lindvall T, Sundell J, eds. Indoor air. Proceedings of the third international conference on indoor air quality and climate. Vol 3. Sensory and hyperreactivity reactions to sick buildings. Stockholm: Swedish Council for Building
Research, 1984:71-7.

26 Beaumont F, Kauffman HF, de Monchy JGR, Sluiter HJ, de Vries K. Volumetric aerobiological survey of conidial fungi in the north-east Netherlands. II. Comparison of aerobiological data and skin tests with mould extracts in an

27 Palmgren U, Strom G, Blomquist G, Malmberg P. Collection of airborne micro-organisms on Nucleopore filters, estimation and analysis-CAMNEA method. $J$ Appl Bacteriol 1986;61:401-6.

28 Mant DC, Muir Gray JM. Building regulation and health. Watford: Building Research Establishment, 1986. 